UDC $339.5+341.24$

DOI: $10.5937 /$ RKSPP2002009B

MICHAEL G. BRIDGE

\title{
INTERNATIONAL TRADE AND TRANSNATIONAL LAW
}

This article deals with the globalisation of contract law. It begins with an historical survey before taking an inventory of the various types of uniform law. These range from 'hard' law, such as multilateral treaties, to 'soft' law, an expression that captures various nonbinding instruments that can usefully be employed by contracting parties and sovereign states. These include contractual standard terms (e.g. Incoterms 2020) and standard form contracts (e.g. ISDA contracts), as well as UNCITRAL model laws. The influence of national law in the globalisation process is noted, whether it takes the form of influencing the laws of other states or provides input into the creation of uniform law. The UN Convention on the International Sale of Goods (CISG) is examined at key points with reference to the influence exerted by the civil law and the common law in its creation. The importance of maintaining the uniform character of the CISG is underlined. Finally, the role played by the UNIDROIT Principles of International Commercial Contracts (PICC) is also examined.

Key words: lex mercatoria, hard law, soft law, uniform law, nachfrist, cure, mitigation

\section{INTRODUCTION}

Although international trade has been with us for or many centuries, we are in modern times dealing with a body of global trading activity that in its volume, intensity and sophistication far exceeds that of the international trade of former

Michael G. Bridge QC (Hon), FBA, Geoffrey Bartholomew Professor of Law, National University of Singapore; Emeritus Professor of Law, London School of Economics; Senior Research Fellow, Harris Manchester College, University of Oxford, e-mail: M.G.Bridge@lse.ac.uk. 
days. Global supply chains and the standards of safety and quality that have ensued from international trading agreements, cross-border relationships and regional associations of states give trade a systematic character that it did not possess even a few decades ago.

It would be entirely wrong, however, to say as we forge forward that we are ignoring the past. It is common nowadays to see and hear references to the lex mercatoria as a body of law to which these cross-border trading arrangements are or might be subject. This expression, lex mercatoria, conjures up a romantic historical vision. In our minds' eyes, we see traders who, even before the fall of the Roman empire, ${ }^{1}$ travelled the silk route or ferried porcelain, jewellery, fabrics and cotton back and forth between China and central Asia; Romans who imported large quantities of Egyptian wheat; and Phoenician merchants who ventured across the Mediterranean Sea and into northern waters, purchasing tin from Cornish miners and trading in spices and linen. Transnational currencies of sorts were developed, taking the form of Greek silver coins, Chinese bronze rings, Indian punched metal discs and even cowrie shells. ${ }^{2}$ After the fall of Rome, to take just a few examples, there were Vikings who navigated the inland waterways of Russia and Ukraine; and Hanseatic merchants in Baltic ports who dealt with pitch, timber, furs and amber. These examples are arbitrarily drawn from a much larger stock of examples. From spot sales of goods in these circumstances, trade evolved over the centuries, to embrace options ${ }^{3}$ and, despite ecclesiastical opposition, forward selling. ${ }^{4}$

Financial instruments like bills of exchange were developed to limit the risks of peripatetic merchants carrying bullion. Goldsmiths took deposits and gave notes in return, transforming themselves over time into bankers. Numerous European cities hosted international trade fairs, with ad hoc netting systems managed by bankers being created to settle, when the fairs closed, the various cross-remittances arising in the course of trading activity. Later, cities like Augsburg and

1 See Cynthia Postand. Edward Miller, The Cambridge Economic History of Europe, Cambridge, 2nd edn, 1987, Vol II.

2 Philip Coggan, More: The 10,000 Year Rise of the World Economy, The Economist Books, London, 2020, 29.

3 The ancient Greeks, apparently, developed the idea of an options contract. As recounted in Coggan, Thales of Miletus, expecting a large olive harvest, took an option on all available olive oil presses for the post-harvest period. See ibidem, 30.

4 It was not until 1826 that courts in England gave a firm ruling that forward selling was not an unlawful wager on future prices: Bryan $v$ Lewis (1826) Ry and Moo 386; cf Lorymer $v$ Smith (1822) 1 B \& C 1, 2. 
Antwerp thrived and declined as centres of international trade and banking. And then came the rise of the Dutch Republic and of Amsterdam from the late $16^{\text {th }}$ century, followed by London in the $17^{\text {th }}$ century and so on.

Complementing this mercantile activity, transnational contract law has also been present since time immemorial in increasing degrees of development to serve the needs of cross-border trade. Even in mediaeval times, merchants would have been conducting business against the backdrop, however hazy and remote, of a law governing their activities. This body of law, referred to as the lex mercatoria, would in mediaeval times have amounted to an agglomeration of usages and customs, applied by merchants themselves in piepowder ${ }^{5}$ and similar courts in the settling of disputes at the periodical trade fairs. ${ }^{6}$ There was also, even in mediaeval times, a transnational admiralty law based on the laws of Oleron, themselves derived from the ancient customs of Rhodes. Marine transportation was more secure and rapid in pre-mediaeval and mediaeval times than land transport. We may have little knowledge of the limited content of this lex mercatoria, ${ }^{7}$ given the scanty documentary record, but its prior existence, before the rise of the modern nation state which captured it and assimilated it as part of a national law, ${ }^{8}$ is a beacon for those who wish to bring it back to life in an enhanced form in modern conditions. For some idealists, this lex mercatoria is romantically invested with an idealised and systematic content and scope that could not have existed in its heyday.

As the modern nation state came into being, a body of centralised law was created that grew to diminish the role of custom and thus also of a separate, unwritten lex mercatoria. The wholesale reception of Roman law in mediaeval Europe from the late $11^{\text {th }}$ century onwards 9 started with the "rediscovery" of Justinian's Corpus Juris Civilis. Its absorption into the bloodstream of European law took centuries to achieve, starting with in the bedding down of Roman law

5 A corruption of "pieds poudrés" (dusty feet).

6 The delays in the administration of justice by local courts were intolerable to merchants who had to be on their way, possibly on the next tide: William John Victor Windeyer, Lectures on Legal History, Law Book Co of Australasia, Sydney, 1949, Ch XXII.

7 For the view that it was largely confined to rules of evidence, proof of sales and contracts, and the taking of deposits as earnest money, see Sir Frederick Pollock, Frederic William Maitland, The History of English Law, SFC Milson, Cambridge, 2nd edn, 1968, Vol. 1, 467.

8 A process that in England was conducted over the 16th and $17^{\text {th }}$ centuries, particularly by the court of King's Bench.

9 See Paul Vinogradoff, Roman Law in Mediaeval Europe, Harper, London, New York, 1909. 
alongside a variety of other legal measures, notably local regulation, feudal dues, royal ordinances and local and regional custom. ${ }^{10}$

With the rise of the modern nation state, there was a discernible movement in continental Europe away from custom to recorded law. France, as a country of the civil law, codified the various regional customs of its central and northern provinces across a period of more than two hundred years, before reorganising them in the form of a civil code in the early $19^{\text {th }}$ century. Germany, as a newly formed nation state, opted at the end of the $19^{\text {th }}$ century for a scientific approach to codification built upon a systematised re-creation of Roman law rather than upon regional German customs. England retained its common law, as it had done with exceptions from mediaeval times. ${ }^{11}$ It resisted codification but slowly systematised that law, which consisted not only of the common law in its narrower sense the product mainly of the courts of common law - but also of equity. Equity, the product of the chancery courts, had a methodology and processes wholly distinct from those of the common law in its narrower sense. It bore down upon the conscience of the individual, that conscience being subjected to exacting procedures, and was in no sense a bureaucratic, formulary system like the common law. This process of systematisation of common law and equity consisted of the improved reporting of judicial decisions, the rise of authoritative legal treatises and improvements to procedure brought about by statute in the $19^{\text {th }}$ century. ${ }^{12}$

The common law was exported to British colonies, but only up to a point. There were areas embedded in local custom, tradition and usage, such as family law and succession, where the common law was not applied to the native inhabitants. France in a similar fashion exported its civil code to its colonies and, in the wake of Napoleonic conquests, carried it to certain other European countries too. The scientific qualities of Germany's code made it an impressive voluntary export product for use in countries such as Japan ${ }^{13}$ and Thailand, ${ }^{14}$ as they were putting themselves through ambitious programmes of modernisation. The first translation into English was carried out by a Chinese scholar shortly after the

10 On the interaction of Roman Law and local law, see Raoul Van Caenegem, An Historical Introduction to Private Law, Cambridge, 1992, 67-71.

11 Those exceptions were admiralty law and, to a lesser extent, equity, which was inevitably influenced by canon law since the Lord Chancellor was for centuries a bishop, and canon law itself was heavily influenced by Roman law. Admiralty law was, after centuries of competition between the admiralty court and the court of King's Bench, finally absorbed by the common law in the time of Lord Mansfield in the third quarter of the $18^{\text {th }}$ century.

12 The bulk of English contract law and the law of sale is a $19^{\text {th }}$ century creation.

13 In 1896 and 1898, working off a draft before the German code came into force in 1900.

14 In 1923. In 1926, Turkey adopted the Swiss Civil Code, itself influenced by the German code. 
BGB's enactment. ${ }^{15}$ All of this may be seen as a wave of globalisation which affected in particular contracts and contract law.

\section{MODERN TIMES}

National law is no longer being exported in a wave of conquest and colonial expansion, but national legal influence is a different matter. Contract law, for example, is experiencing a process that can loosely be termed globalisation. This is occurring in various ways. The first of these ways is the creation of uniform law, cutting across national borders, which may take the form of "hard" law, such as international treaties, or of "soft" law, such as standard terms of contract offered to the mercantile community for incorporation in their contracts (for example, The Uniform Customs \& Practice for Documentary Credits - UCP600) or even complete standard contracts (for example, the ISDA Multi-Currency Cross-Border Master Agreement and the recent ICC Model Contract for the International Sale of Manufactured Goods). A hybrid phenomenon is the model law proffered by an international organisation, for example, the UNCITRAL model laws dealing with international arbitration and secured transactions. After centuries of national legal experience, it is rare to find novelty in uniform law that does not take its inspiration from one national law or another. National influences are brought to play in the creation of a hybrid uniform entity. To take an example of this, the European Union has a significant range of national examples from which to select or choose when formulating regulations and directives, in the way that a printer or an author has a variety of fonts at its disposal.

A second pathway to the globalisation of contracts law consists of the adoption of another country's laws, sometimes modified to suit local conditions. There is some evidence of this today, though not on the ambitious scale stated earlier that featured the German Civil Code. Singapore, for example, continues to adopt particular UK statutes, dealing for example with bills of lading and related transport documents, third party contract beneficiaries and reforms to the law of sale of goods. The two national bodies of law are already very similar and Singapore is able to draw upon the legal resources of a significantly larger country in carrying the law forward so as to improve the attractions of its commercial law. ${ }^{16}$ Adoption can also take the form of incorporating international uniform law into domestic

15 Chung Hui Wang, The German Civil Code: Translated and Annotated, Stevens, 2007.

16 At the same time, however, it is building up an impressive range of judicial precedents reducing any need for a Singapore court to turn to English and Australian decisions instead of to the prior decisions of the Singapore courts themselves. 
law. Examples of this are the incorporation of the UN Convention the International Sale of Goods (CISG) into the domestic law of Norway and Israel. The UNIDROIT Principles of International Commercial Contracts (PICC) have been brought in to reshape Lithuanian domestic contract law as the country was converted from a planned, socialist economy to a western market economy. One of the purposes served by the PICC is indeed "to interpret or supplement domestic law". ${ }^{17}$

A third pathway to the globalisation of contract law is seen in the widespread use of particular national laws in international contracting. Take the case of English law in commodity trading, in very many instances where there is no physical connection between the contracting parties or the place of performance and England. English law dominates the trade in grain and soya between North and South America and northern Europe ${ }^{18}$ without any significant part in this trade being played by English (or UK) traders. It plays also a major role in contracts concerning crude oil, again very commonly in cases where the parties and the performance of the contracts have no physical connection with England. ${ }^{19}$ In the commodities trades in general, whether we are looking at physical or derivatives trades, the CISG is excluded in favour of a national law. This has at least as much to do with an acceptance of the settled state of international trading in those commodities as it has with some degree of concern about the suitability of the CISG for dealings in commodities in dynamic and sometimes turbulent markets. In these markets, the phenomenon of string trading is commonplace, involving dealings in the same type and quantity (or divisible portions thereof) of goods priced in the same currency as goods, evidenced by paper, pass down from an initial seller to an ultimate buyer. The choice of the same applicable law down the string is part of this uniform package and enhances the tradability of the goods subject to the contract. ${ }^{20}$ Commodities traders are not nationalistic or sentimental when it comes to the choice of the applicable law. To take another example, the preferred choices in the derivatives trades (futures, swaps and options) are English law and New York law. ${ }^{21}$

17 Preamble of the PICC.

18 GAFTA (the Grain and Agricultural Feed Association) claims that $80 \%$ of world trade in grains is conducted on the basis of its contract forms. These forms specify the use of English Law and explicitly exclude the CISG and Incoterms. sol (Spain).

19 There are numerous examples, eg Total (France), Chevron (US), Neste (Finland) and Rep-

20 The number of contracts concerning cargoes of commodities often far exceeds the number of physical cargoes.

21 As noted by the Financial Markets Law Committee in 2008: Issue 130 - Implementing the Vienna Sales Convention, paras 4.8 et seq. The FMLC's concerns about the unsuitability of the CISG 


\section{UNIFORM LAW}

The second and third methods of globalisation stated above repay careful study but for the remainder of this article I propose to concentrate on uniform hard and soft law, with particular reference to the CISG as hard law and the PICC as soft law. These are both substantive law instruments. It goes without saying that there are also striking examples of measures dealing with procedural issues that affect the environment of commercial contracts. Examples that come immediately to mind are those dealing with jurisdiction and enforcement of judgments, whether stemming from regional initiatives, for example the EU Brussels I Regulation, or from universal initiatives, for example the somewhat limited Hague Convention on Choice of Court Agreements ${ }^{22}$ and the New York Convention on the Recognition and Enforcement of Foreign Arbitral Awards. Again, we should not lose sight of conflict of laws measures, largely stemming from the work of the Hague Conference on Private International Law, such as the Hague Sales Conventions of 1955 and 1986. In standardising the approach to selecting the law applicable to a contract, they do not as such concern substantive law.

Taking now the case of hard uniform law, a striking example concerns carriage of goods by sea. For almost a hundred years, uniform rules adjusting the balance of hull and cargo interests have been in place. This started with the Brussels Convention 1924, ${ }^{23}$ which gave us the so-called Hague Rules on the liability of cargo carriers. The process then ran on to the variation known as the Hague-Visby Rules 1968, ${ }^{24}$ with a diminished number of Contracting States. Concerns that cargo interests and non-coastal States lacking maritime assets were insufficiently catered for led to the Hamburg Rules $1978^{25}$ and finally to the Rotterdam Rules. ${ }^{26}$ The difficulties of bedding down uniformity in this area arise from the perennial tension of hull interests and cargo interests, the development of containerised transport, and the question of how far these rules should extent to connec-

centred particularly on the Convention's potential application to physically settled OTC transactions in commodity derivatives.

22 In force 2015 with 32 Contracting Parties.

23 The International Convention for the Unification of Certain Rules of Law relating to Bills of Lading ("Hague Rules") and Protocol of Signature.

24 The Protocol to Amend the International Convention for the Unification of Certain Rules of Law Relating to Bills of Lading (the so-called Brussels Amendments). A further Protocol dealing with special drawing rights was concluded in 1979.

25 In force 1992 (but the major trading nations have not adopted the Convention or even, in some cases, signed it).

${ }^{26}$ Not yet in force. 
ted on-shore operations, such as inland carriage, warehousing and stevedoring. Further examples of uniform hard law to note in passing are the Warsaw Convention for the Unification of Certain Rules Relating to the International Carriage of Goods by Air 1929, the Athens Convention Relating to the Carriage of Passengers and their Luggage by Sea $1974,{ }^{27}$ the Convention on the International Carriage of Goods by Road (CMR), ${ }^{28}$ and the Convention on International Carriage by Rail (COTIF). ${ }^{29}$ Given the constraints of space and the great success of the CISG, as well as the potentiality of it for relations with soft law, namely the PICC, I propose to focus on the CISG.

\section{THE CISG}

It came into force in 1988 and has proved to be a great success, with 93 Contracting States to date, Brazil and Vietnam being among the more recent adherents. The CISG endured a lengthy gestation period. It was preceded by the efforts of the great German jurist Ernst Rabel prior to the Second World War, and by the two conventions on international sale that were the product of a conference held at The Hague in 1964. But the CISG came into being as a result of the efforts and energy released in the late 1960s when the newly created UN Commission on International Trade Law (UNCITRAL) became involved in the unification project, largely as a result of the belief that a uniform sale convention could be an instrument of the so-called new international economic order, which was a fashionable idea at the time. ${ }^{30}$ The 1964 Hague conventions were unsuccessful, adopted by only a handful of western European countries, often with substantial opt-outs, together with Israel and Gambia. Countries with socialist economies, as well as North America and the world of developing economies, did not participate in the process of concluding the conventions. It is an elementary proposition that the chances of widespread adoption of a multi-party convention depend heavily upon the engagement of as many countries as possible in the process of creating them. This creates a sense of ownership. As a result of these failings in the 1964 conventions, the way was open for the initiative that gave us the CISG.

27 As amended by a Protocol of 2002. See Paul Mybergh, "A Successful Substantivist CarveOut?: The Athens Convention as Uniform International Law", Journal of Business Law, 2020, 20.

28 A UN Convention has been in force since 1962.

29 An inter-governmental convention concluded in 1980 and containing uniform rules for passengers (CIV) and for freight (CIM).

30 It occupies a prominent place in the Preamble to the CISG but has had no impact on the development of the CISG since it came into force. 
As a result of the creation of UNCITRAL, 62 countries (as well as eight organisations) participated in the international conference held in Vienna in 1980, two years after the preparation of the Draft Convention in 1978. ${ }^{31}$ The CISG entered into force in 1988, having acquired the necessary number of Contracting States. The ensuing success of the CISG was due not only to the number of participants taking part in the process but also to the recognised presence of the diverse national legal influences that were fed into the CISG. In the years immediately after the entry into force of the CISG, though less so in recent years, much was made in the literature of the various polarities at work in the process of its creation. These included the tension between capitalist and socialist economies, between north and south, and between civil law and common law. The impact of the socialist countries is evident in the opt-out provided by Article 96 CISG from the rule of informality in the making of contracts, ${ }^{32}$ which would otherwise have been a problem for planned economies, ${ }^{33}$ but is barely observable elsewhere. As for the north and south polarity, the scope to be given to established commercial usage and the time given to buyers to serve notice of defects on their seller was a point of sensitivity for developing countries in the drafting process. ${ }^{34}$ Apart from these matters, the conflict between north and south is scarcely evident in the CISG. By far and away the most significant polarity was that between civil law and common law and the tensions between the two are evident in numerous instances.

I have no desire to attempt some sort of numbers count to determine whether it was the civil law or the common law that had the greater impact on the composition of the CISG. That would amount to an unseemly competitive game when the issue is uniformity and multiple States moving forward together in a common cause. Both systems contributed to the CISG and each had to make concessions to the other. It is, however, appropriate and interesting to investigate some of the influences of those two systems of law on the overall CISG and to inquire how well a convention works when it borrows and mixes from the two legal traditions. The danger in conducting an exercise of this sort is that it assumes a monolithic civil law and a monolithic common law, when their defining featu-

31 A smaller number participated in the Working Groups that produced the text (initially, 29 then later 36 states).

32 Article 11 CISG.

33 The opt-out was also taken by a number of South American states.

34 As recounted by the Ghana representative (Date-Bah) in March 1980 during the deliberations of the First Committee in its 16th meeting (A/CONF.97/C.1/SR.16) and 21st meeting (A/ CONF.97/C.1/SR.21). 
res are often more a matter of legal method than of substantive legal content. ${ }^{35}$ No one should assume that, for example, French and German law in a civil law tradition stemming from Roman law are as identical as Romulus and Remus, or that English and US law in the common law tradition finish each other's sentences. I propose to select a number of features of the CISG that derive from the separate traditions, and to select also a number of examples that show an interesting conjunction between them. I shall begin first from the point of view of the civil law before proceeding to the common law.

\section{Civil law}

The civil law invests much greater importance, in theory at least, to requiring performance as a remedy for breach of contract than does the common law. It is well known that in common law systems the primary remedy for breach of contract is damages. Specific performance at common law is a discretionary remedy called into play in rare cases where damages would not be an adequate remedy ${ }^{36}$ In the civil law, on the other hand, there is no corresponding restriction of a formal kind on the enforced performance of a contract. ${ }^{37}$ This may originally have been due to a fuller commitment to the principle of pacta sunt servanda in the romano-canonical tradition, but what may once have been a matter of faith can over time become a matter of entrenched habit. This approach to the enforced performance of contracts is repeated in the CISG in Articles 46 and 62 (though Article 28 CISG allows common law countries to opt instead for damages in defined circumstances). ${ }^{38}$ These provisions lay down a right to require performance, restricted only in the case where a seller has delivered defective goods (Article 46(2) CISG), which amounts to an oblique retention of the otherwise rejected critical distinction, especially prominent in the civilian tradition, between non-per-

35 In the case of some civil law countries in particular, and partly at least because of the CISG, there have been significant changes made to update contract law. These countries include France (Ordonnance $\mathrm{n}^{\circ} 2016$-131 of 10 February 2016 on the reform of contract and obligations in general), Germany (Act on the Modernisation of the Law of Obligations, in force 1 January 2002) and Turkey (Code of Obligations 2012).

36 Sale of land cases constitute an exception to the general disposition not to award specific performance in view of the (supposed) uniqueness of individual parcels of land.

37 Contracting parties, nevertheless, may well prefer to go to the market place rather than to await the outcome of litigation for enforced performance.

38 Article 28 CISG does not explicitly mention common law countries but it uses for the only time in the CISG the common law expression specific performance instead of requiring performance, elsewhere used in the CISG. 
formance and non-conforming performance. ${ }^{39}$ In the reported decisions, nevertheless, there are few signs of direct performance being required of, instead of damages being awarded against, the non-performing party. It takes a great deal patience for a contracting party in the case of goods to spend time litigating for enforced performance in a moving world. The commitment in law to enforced performance is more a matter of tradition and dogma than practicality.

The civil law, as is well known, knows no doctrine of consideration and there is no acceptance of that doctrine, express or implied, in the CISG. In any case, the doctrine would not pose any problems to the conclusion of a contract of sale since the seller's promise to supply and the buyer's promise to pay constitute consideration for the other party's promise. In the formation of a contract of sale, however, the civil law view that an offer is capable of giving rise to a binding promise even before acceptance has prevailed. ${ }^{40}$ Hence, there is Article 16(2) (a) CISG, which provides that an offer may not be revoked if it indicates that it is irrevocable by stating a fixed time for acceptance or by other means. This amounts to a firm rejection of classical common law doctrine, whereby a promise to keep an offer open is not binding in the absence of consideration for the promise. That classical view was nevertheless rejected in Article 2 of the American Uniform Commercial Code, which is the source of an alternative means in the CISG by which an offer may not be revoked. According to Article 16(2)(b) CISG, an offer is irrevocable if it was reasonable for the offeree to rely upon it as irrevocable and the offeree has so relied. Although the issue does not surface under the CISG, the notion of obligation stemming from reliance rather than promise does raise the issue of how far should liability go: should it be confined to an injurious change of position by the promise, or should it go further and embrace the full extent of the promise contained in the offer?

The rejection of the doctrine of consideration also assumes practical importance when the contract has already been concluded and the parties then proceed to an agreed variation of the contract. Article 29 CISG makes it very clear that the "mere agreement" of the parties is sufficient to give rise to a binding variation. In the modification and variation of contracts, there is therefore no place in the CISG for this common law doctrine. The common law requirement of consideration may be seen as having a connection with the refusal of some common law countries to look at subsequent conduct when interpreting contracts, ${ }^{41}$ which

39 Discussed below.

40 Hence, from a common lawyer's point of view, before consideration is given for the promise in the offer.

41 England in particular. 
is not something that should trouble courts in civil law countries. It is noteworthy that Article 8(3) CISG permits a reference to subsequent conduct when a contract comes to be interpreted. This accords with the view that a contract is not so much an artefact fixing irrevocably the position of the contracting parties at a single point in time but rather a continuing relationship. It is necessary to establish an agreement in the first place so as to bind the parties, but the agreement thereby reached may evolve into something different.

A celebrated feature of German law, concerning untimely performance, is the so-called nachfrist doctrine. According to this doctrine, as incorporated in the CISG, one of the contracting parties, faced with a delay by the other in the performance of the contract, may fix a time for that performance to take place. In the event that performance still does not occur, the party serving the nachfrist notice may avoid ${ }^{42}$ the contract (Articles 49(1)(b), 64(1)(b) CISG). In the case of English law, the position is complicated by the way that, for delivery in commercial sale contracts, it has long been the position that time is of the essence of the contract in the first place without any need of a subsequent notice. ${ }^{43}$ The opposite is the case of sale of land, owing to the greater difficulty of establishing title and performing the contract. There is in these latter instances a long history of time notices being served but the efficacy of this process has been called into question, owing at least in part to the conviction that a contracting party may not unilaterally vary the contract. If time was not of the essence when the contract was concluded, why should one party acting unilaterally be able to alter that? There is no statutory entitlement to make time of the essence of a contract when it was not already so in the first place. One judicial attempt to treat failure to comply with a notice as nonperformance rather than merely untimely performance ${ }^{44}$ came to grief. ${ }^{45}$ This complexity does not of course bear upon the provisions of the CISG. That said, one cannot assume that any complexities associated with the German nachfrist doctrine in German domestic law should apply also in the case of the CISG. The provisions of the CISG are clear and should not come with baggage from any national legal system. Article 7(1) CISG mandates the uniform interpretation of the Convention in a way that befits its national character. ${ }^{46}$ The same caution against importing domestic colouring should also be displayed when it comes to fitne-

42 In the sense of terminate.

43 See, eg, Bunge Corp v Tradax Export SA [1981] 1 WLR 711.

44 See Multi Veste 226 BV v NI Summer Row Unitholder BV [2011] EWHC 2026 (Ch).

45 In Samarenko v Dawn Hill House Ltd [2011] EWCA 1145, [2013] Ch 36.

46 See also below. 
ss for purpose in Article 35 CISG: fitness for purpose has been present in English law since at least $1829 .{ }^{47}$

A further inheritance in the CISG from the civil law tradition concerns the price reduction action in Article 50 CISG. Under this provision, the buyer may unilaterally discount the price of non-conforming goods in line with the degree of their non-conformity. Common lawyers may believe that this is a type of damages action based on establishing the extent to which the buyer's performance interest in the contract has been prejudiced. But the location of the action in the CISG, where it is distant from the general damages action in Article 74 CISG, is revealing. Article 50 CISG does not as such constitute a damages action but is instead a provision conferring on the buyer a right to revise the contract in part. In practical terms, however, the effect of a price reduction action may have some similarity with an action for damages under Article 74 CISG. On its terms, Article 74 CISG is certainly capable of producing an award representing the difference in value between conforming and non-conforming goods, but the difference between the two actions becomes apparent in market conditions, when the timing of the process differs in the two cases. ${ }^{48}$ It also becomes apparent in those cases where the non-conformity of the goods causes no loss to the buyer who is able to use or dispose of them without incurring any financial loss. ${ }^{49}$ If the non-conformity of the goods does not injure the buyer, the buyer may nevertheless claim under Article 50 CISG for the diminished value of the goods. ${ }^{50}$

Some emphasis should be placed on features of the CISG representing a surrender of the civil law position. For example, the notion that damages for nonconforming goods should not be available in the absence of the seller's fault ${ }^{51}$ is excluded from the CISG. In some systems, this feature has been attenuated by presumptions of knowledge of latent defects in the case of professional sellers. ${ }^{52}$

47 Jones $v$ Bright (1829) 5 Bing 533. The civil law guarantee against latent defect is not as such known in common law countries.

48 In English law, a damages claim measures the difference between the actual value of the goods at the time of delivery and the value they should have had at that time if they had been conforming goods. The sale price itself does not come into the comparison. Under Article 50 CISG, the difference between the two values give rise to a fraction that is applied against the contract price.

49 Bence Graphics International Ltd v Fasson UK Ltd [1998] QB 87.

50 And if the non-conformity causes damage over and above diminished value, the buyer may claim additionally damages under Article 74 CISG.

51 On the fault principle, see Hein Kötz, European Contract Law, Oxford, 2nd edn, 2017, 244-48.

52 Under Article 1645 of the French Code civil, a seller's liability in damages, going beyond the restitution of the price, is confined to cases where the seller knew of the defect. The courts have 
German courts, for example, have loyally declined to give an excessively wide interpretation to Article 79 CISG, which exempts parties from liability where events render impracticable the performance of a contract, so as to exonerate a seller who is free from personal fault. ${ }^{53}$ Similarly, again in connection with non-conforming goods, a long-standing distinction, particularly apparent in German law, between non-performance and non-conforming performance, has been given up. ${ }^{54}$ The effect of a global instrument on domestic law should be noted here. In 2002, Germany revised its civil law so as to remove this feature from its civil code and, in certain other respects too, to bring the code into line with the CISG. ${ }^{55} \mathrm{~A}$ systematic codal system is naturally intolerant of incongruities between domestic law and an international convention as incorporated in national law. A common law system, in comparison, can shrug off such incongruities. ${ }^{56}$ Tidiness is not a characteristic of the common law. ${ }^{57}$

\section{Common law}

Certain features of the CISG have specifically been drawn from Article 2 of the Uniform Commercial Code (UCC), thus reflecting the energy that the United States pours into the various projects carried on in UNCITRAL (a clear example of this is the work on secured transactions reform). Perhaps the most prominent feature is the doctrine of cure, for which, at least in the French case law, there is no precedent. ${ }^{58}$ The essence of the seller's right to cure is that the seller in

developed an evidential presumption of fault in the case of professional sellers: Cass. Civ. 1re, 24 November 1954; JCP 1955.II.8565.

53 Bundergerichtshof 24 March 1999 (the Vine Wax case).

54 But Zimmermann asks the question whether a seller who delivers a bag of coal instead of a Picasso has to be treated as having delivered a defective Picasso. See Reinhard Zimmermann, The New German Law of Obligations, Oxford, 2005, 116.

55 See ibidem, 40.

56 Hence, when the European Directive on the sale of goods and associated guarantees (1999/44/EC) was transposed in English law (first as Part 5A of the Sale of Goods Act, then subsequently by the Consumer Rights Act 2015), its features concerning enforced repair and substitution had no effect on the general attitude towards specific performance in the law of contract.

57 Lord Diplock once memorably described the common law as a maze and not a motorway in Morris v CW Martin \& Sons Ltd [1966] 1 QB 716.

58 Jérôme Huet, Traité de droit civil. Les principaux contrats spéciaux, LGDJ, 2001, 11754 (droit de "porter remède"). See also Michael Will, "Article 48", Commentary on the International Sales Law, Michael Joachim Bonell, C. Massimo Bianca (eds.), Milan, 1987, 437-448. Absent in the former provisions of the French Code civil, cure was not incorporated when the contract provisions were recently revised. 
stated circumstances is permitted to correct a non-conforming tender or delivery. In UCC Article 2-508, perhaps the most important characteristic of cure is that it prevents a surprise rejection of the goods, with its ensuing termination of the contract, by the buyer further to the perfect tender rule in UCC Article 2-601. It is clearly presented as a right given to the seller to correct a non-conforming tender or delivery. Transplanted into the CISG as Article 48 CISG, cure has no such corrective action to perform because the CISG contains no perfect tender rule. Indeed, the rule of fundamental breach in Article 25 CISG requires such a marked departure from the standard of performance demanded by the contract that there will be few circumstances in which a breach will be so serious as to trigger a right to terminate (avoid) the contract.

The drafting of Article 48 CISG leaves a lot to be desired. On one view, the seller merely has a right to propose cure to the buyer, who may reject the seller's offer and claim damages or a price reduction, except in those cases where there is a fundamental breach and the seller wishes to take steps to prevent the buyer from avoiding the contract in accordance with Article 25 CISG. Although paragraph (1) states the seller's right to cure, paragraph (2) then goes on to discuss the buyer's decision whether to accept the proposed cure. It hardly seems to have been worth the legislative effort to give the seller a so-called right to cure if this can be blocked so easily by the buyer and if it amounts only to a right to speak to the buyer. Moreover, the Secretariat Commentary explicitly states that a cure may be imperfect so as to convert a fundamental breach into a lesser breach, which clearly points to the seller's cure being imposed on the buyer. Another, and clearly preferable, view therefore is that the buyer may only set or define the circumstances in which the cure is to occur (such as time and place). If the latter view is correct, it draws attention to the way that a seller's right to define the cure sits uncomfortably with the buyer's right to require performance in Article 46 CISG. May the seller insist on repair if the buyer demands substitute goods under Article 46(2) CISG in cases of fundamental breach? May the buyer in other cases insist on repair if the seller prefers to supply substitute goods?

Another import from Article 2 that may be criticised as a failed transplant concerns the giving of adequate assurance of due performance. This avails a contracting party who is placed in a position of uncertainty with respect to the other party's willingness or ability to perform the contract. ${ }^{59} \mathrm{~A}$ contracting party who is in some doubt about the existence of a right to terminate may itself commit a terminating breach of contract if it refuses to perform when its own right to terminate is not available. What amounts to adequate assurance is very hard to say.

59 Article 2-609, applicable when "[r] easonable grounds for insecurity arise”. 
In a given case, it might lie somewhere in a range stretching from soothing words to a performance bond, though the latter might seem to be an extreme form of assurance in view of the cost it imposes on the party required to provide assurance. It is fair to say that what amounts to adequate assurance is in both general terms and in the specific case hard to state with any precision, but the presence of this rule again serves to blunt the edge of strict termination rights. Once again, the absence of such rights in the CISG, where the adequate assurance rule operates somewhat differently to the way it does in Article 2, points to the transplantation of a rule into a different setting (the CISG) where its purpose, effect and utility are very difficult to determine.

More effective imports from the common law exist. The rule of mitigation of damages, which prevents an obligee from sitting on its contractual rights in the face of a breach, when it might have exercised self-help to stem losses flowing from the breach, has no specific equivalent in French law, for example. ${ }^{60}$ Another point of departure from French law concerns the common law's greater willingness to enforce a contract that contains no mechanism for determining the price. The CISG is notoriously opaque in that it contains seemingly conflicting provisions (Articles 14 and 55 CISG) that give comfort to both positions. ${ }^{61}$ The process of creating uniform law is perfectly capable of producing a compromise text that makes conflicting parties content, or at least not discontented, which is a common feature of the diplomatic process. This is a matter of some discomfort for some American academic lawyers who see compromises of this sort as leading to inefficient outcomes. ${ }^{62}$

\section{Conjunction of civil law and common law}

A global instrument that draws from more than one legal tradition to create a composite whole can acquire internal tensions from that dual inheritance. We have already seen the tension that exists between the seller's right to cure and the buyer's right to require performance. A further example often mentioned is present in Article 8 CISG, which seeks to balance civilian subjectivism and common

60 Despite the adoption of the CISG by France, the mitigation rule has not been incorporated in the revised provisions of the Code civil.

61 Article 14 CISG appears to require the price to be determined whereas Article 55 CISG clearly recognises that the price may not, whether expressly or impliedly, be fixed.

62 And some English judges too, mindful of the adage that a camel is a horse designed by a committee. See Sir John Hobhouse, "International Conventions and Commercial Law: the Pursuit of Uniformity”, The Law Quarterly Review, Vol. 106, 1990, 530. 
law objectivism in the meaning of language and contracts. It gives primacy to the civil law approach of subjective intention before turning to the common law approach if subjective intention cannot be determined. This is really a false conflict because a party's subjective intention governs only if the other knew or could not have been unaware of that intention. Objective intention only comes into play when the reasonable bystander, standing in for the other contracting party, is unaware of that subjective intention. Article 16 CISG is an example of alternative routes to commitment in the shape of a binding offer. Following the civil law, an offer is binding if it is states a fixed time for acceptance or otherwise indicates its irrevocability. Borrowing from Article 2 of the UCC, but not English common law, Article 16 CISG also provides an alternative route to irrevocability in the shape of the offeree's reasonable reliance on the offer staying open. The two approaches sit very uncomfortably side by side. A final example concerns nonconforming goods. Putting aside the possibility of a consequential damages cla$\mathrm{im}$, there is nothing to indicate whether the buyer's claim is confined to a price reduction action (Article 50 CISG) or whether the buyer may instead opt for a claim for damages claim (Article 74 CISG), with different outcomes in dynamic markets. The damages approach would give the buyer the difference between what the goods should have been worth at the point of delivery and what in fact as non-conforming goods they were worth at that time. This does not involve a direct reference to the price. The price reduction approach, however, as noted above, is to take this difference between the two values at the point of delivery and use it as a fraction to reduce the sale price.

\section{Maintaining uniformity in the CISG}

A uniform instrument in force in more than 90 countries, implemented by judges and arbitrators of divergent legal backgrounds, courts the risk of being absorbed into different legal cultures and, in its implemented form, losing its uniformity by "going native". Like a sunken ship that becomes encrusted with barnacles, the uniform instrument risks acquiring in each country a separate identity. The process is not dissimilar to the way that separate languages are created from a common stock. The architects of the CISG were well aware that national legal culture might come into play in judicial decisions and arbitral awards so as to transform the meaning of the uniform instrument this possibility. To avert this possibility, Article 7(1) CISG imposes an obligation on courts ${ }^{63}$ to promote uni-

63 As entities of the Contracting State. No such obligation could be imposed on arbitrators as such and the very light controls exercised over international arbitral awards by the New York 
formity in the application of the CISG by respecting its international character. No guidance is provided by the CISG as to how uniformity is to be promoted. It is not to be done by the creation of a system of binding international precedent. There is scope, nevertheless, for a nuanced distinction between binding authority and persuasive authority, which in any case would be anathema to many civil law countries. There is, furthermore, no international commercial court to provide something in the nature of a guiding light for the interpretation of the CISG. By means of the so-called CLOUT ${ }^{64}$ system of recording judicial decisions and arbitral awards on the CISG, UNCITRAL, with the aid of volunteer national reporters, seeks to educate the international legal community on the development of the CISG. One obvious way of promoting uniformity, in the absence of a supranational international commercial court, is through the dissemination of national decisions. The CLOUT system is maintained in the six official languages of the United Nations. This documentary record, however, consists only of case summaries, which may give only a superficial account of the way that the CISG has been applied in a given instance. UNCITRAL similarly maintains a digest of cases, updated from time to time, but the entries for each case are very brief. Furthermore, following United Nations policy in this regard, the digest is not critical of the decisions themselves. This digest, however, by the simple device of grouping cases into particular interpretations of the text, may give later courts an indication of both orthodox (majority) and wayward (minority) decisions. Taking the two instruments together, it has to be accepted that decisions and awards play at least an influential role in the development of the CISG. If this were not the case, it is hard to see why UNCITRAL would have gone down this road if recorded case law was not to have at least persuasive authority. How can a court comply with its uniformity obligation in Article 7(1) CISG if it does not take account of what other courts and tribunals are doing? The CISG is not an instrument that burst into force fully-formed in 1988; it is instead a current, living instrument.

UNCITRAL has limited resources and a limited role when it comes to policing and supervising the development of the CISG. More ambitious attempts to maintain uniformity may be found in the private sector. A number of excellent websites may be found where decisions are recorded in full. The most famous example was created by Pace University under the name of its creator, Professor

Convention on the Recognition and Enforcement of Foreign Arbitral Awards 1958 would not equip courts with adequate tools to exercise control of these awards.

${ }^{64}$ Case Law on UNCITRAL Texts. 
Al Kritzer. ${ }^{65}$ Regrettably, the website has not been updated in the last few years. It still has some utility, albeit diminishing, in setting out in accessible form a bank of books, articles, essays, theses and notes dealing with the CISG, much of which may be fully downloaded. One criticism, however, is that the website in its abundance does not differentiate between the good and the bad and mediocre, which diminishes its utility for judges and practitioners. The first port of call for them has become the various commentaries on the CISG. More important than the record of writings on the CISG is the way that the Pace website, relying upon volunteer translators, records well over a thousand decisions that have been translated into English. Uniform law does not survive linguistic misunderstanding or ignorance, and this initiative builds upon the widespread status of English as a second language. Similar in a way to the Permanent Editorial Board of the American Uniform Commercial Code is the CISG Advisory Council ${ }^{66}$ of which I am the current chair. The Council, taking references from individuals and institutions, issues pronouncements on particular problems or particular provisions of the CISG in the form of black letter rules and commentary. The black letter rules constitute the first port of call with the commentary coming into play when further elucidation is needed. As a private and independent body, the influence of the Council is measured by the quality of its work. To repeat a statement made about Roman law in mediaeval Europe, it is authoritative imperio rationis and not ratione imperii.

There are also other forces of uniformity at work. Not to be underestimated is the effect of students studying the CISG in other countries as part of their LLM studies, or taking part in mooting competitions like the Willem C Vis Moot. In time, many of these students will in turn become judges and arbitrators. There is now a large global community of CISG scholars and exponents and they talk to each other. This does not mean that the distorting effect of national legal culture has been effaced for evermore. The first few years of a legal education are the most critical in influencing a lawyer's development. The different ways in which the line is drawn between questions of fact and questions of law threatens distortion, alongside different approaches to the location of the burden of proof. Locating the boundary between the law of tort (or delict) and the law of sale is another area ripe for divergence. There is also the issue of gaps in the CISG, which I shall turn to when considering the PICC.

\footnotetext{
65 See www.cisg.law.pace.edu.

66 See www.cisgac.com.
} 


\section{PICC}

The Principles of International Commercial Contracts, promulgated by UNIDROIT, ${ }^{67}$ are a prominent example of a global soft law instrument, "designed for use throughout the world irrespective of legal traditions and the economic and political conditions of the countries in which they are to be applied". ${ }^{68} \mathrm{In}$ addition to the PICC, there are other highly successful examples in the form of standard contractual terms that parties are free to incorporate in their contractual dealings. These include the York-Antwerp Rules on General Average and instruments published by the International Chamber of Commerce (ICC), notably Incoterms 2020, on the meaning of standard delivery expressions such as CIF and FOB, and UCP 600 (2007), which concern the customs and practices of documentary letters of credit, with particular reference to the relationship between the beneficiaries of letters of credit and issuing and confirming banks. It is hard to overestimate the boost given to global trading by the work of the ICC.

Considerations of space and time, as well as the complementarity of the CISG and the PICC, compel me to concentrate on the PICC at the expense of other soft law instruments. The first issue is to define what is meant by the commonly used expression "soft law" instrument. The PICC do not purport to be a code of contract law binding parties who enter into contracts that may be characterised as international. They do not derive any binding force from a treaty, or from any national legal system. On their face, however, they are a codification of contract rules, far more extensive than any implant in a contract such as Incoterms 2020. They differ from the form of a conventional code of contract law in that they come with comments and illustrations on top of black letter rules. There are rules on contract formation, vitiating factors, performance, breach of contract and remedies. Furthermore, the Preamble claims that they "shall" be applied, inter alia, when chosen by the parties and "may" be applied when whenever the parties have not chosen any applicable law or when they have used an expression such as "the lex mercatoria or the like". These are claims that, especially the first, cannot derive their force from the PICC themselves, for it is down to national rules concerning choice of law and the governance of arbitrations to determine these matters. A further claim to self-sufficiency comes in the form of a rule that the parties may not exclude the duty of good faith and fair dealing set out in the PICC (Article 1.7 PICC), which is a strange thing to find in a non-normative

67 The International Institute for the Unification of Private Law.

68 Introduction to the first edition (1994). 
instrument. It is rather like an artist's assertion of moral right so that the integrity of a work of art may not be compromised by outside interference in its presentation. ${ }^{69}$ The same objection to the self-proclaimed binding force of the PICC cannot be made of the Preamble's claim that they may serve as a model for national legislators, but the further claim that "[t]hey may be used to interpret or supplement international uniform law instruments" is more problematical. That is a matter for the organisation promulgating the uniform instrument and for Contracting States. These latter cannot be bound by the pretensions of an outside entity, in this case UNIDROIT. ${ }^{70}$

In this last regard, let us consider now the relationship of the CISG and the PICC. We may begin with the observation that a country's rules on contract law are embedded in a greater whole of rules dealing with matters such as property law and civil liability for torts or delicts. A country that incorporates the CISG for international sale contracts is incorporating something that does not come with collateral support and boundary definition in the shape of uniform general contract, property and tort rules. If we could confine ourselves to their style and similarity of approach, there is a case to be made for combining the CISG and the PICC, though such a combination will amount to less than a comprehensive body of private law embracing the whole of the law of sale. ${ }^{71}$ The PICC were inspired by the success of the CISG and a number of the persons taking part in national delegations leading up to the CISG were also rapporteurs for the PICC. Given that the PICC cannot of their own motion supplement the CISG to create a greater global law of contract, can this be achieved by other means?

First of all, there is the possibility that the parties themselves may choose the PICC as the applicable law of the contract alongside the CISG. It is debatable whether this will be effective in later judicial proceedings; it depends upon whether a country's rules of private international law will accept as the applicable

69 In the 1980s, an artist, whose work included a skein of wild geese suspended from the ceiling of a shopping centre in Toronto, successfully challenged the hanging of Christmas ribbons from the geese: Snow v Eaton Centre Ltd (1982) 70 CPR (2d) 105.

70 Some sense of the sensitive character of the relationship between the CISG and the PICC can be gained by comparing the initial and subsequent drafts of a document (Legal Guide to Uniform Legal Instruments in the Area of International Commercial Contracts (with a focus on sales)), March, 2020, issued under the joint aegis of the Hague Conference on Private International Law, UNCITRAL and UNIDROIT. The original document is available at $h t t p s: / / w w w . h c c h . n e t / e n / g o v e r n-$ ance/council-on-general-affairs and the document containing the adjustments, a UN document, is available as A/CN.9/1030.

71 Neither instrument deals with the transfer of property rights. 
law a body of rules that is not state-based law. This is not the case, for example, for EU countries subject to the Rome I Regulation, ${ }^{72}$ though this restriction does not affect the choice of the PICC in the case of arbitration. ${ }^{73}$ Furthermore, although the CISG, when otherwise applicable, may be excluded by the parties themselves (Article 6 CISG), it is not clear what the effect of an applicable law clause would be. Would it signify an attempt to exclude the CISG altogether, or to exclude the CISG only when its rules are at variance with the PICC, or merely to supplement the CISG when this instrument is otherwise silent (either because a contractual issue does not pertain to the special case of sale or because, while it does, there is no express or implied rule in the CISG that meets the case)?

Assuming there is no applicable law clause favouring the PICC, may they be brought in to assist the CISG by virtue of the CISG itself? In a famous provision, Article 7(2) CISG, the CISG states that, where the CISG is silent on an issue that falls within its scope, recourse may be had to the general principles on which the CISG is based, failing which resort may be had to the applicable law. Now, it is perfectly possible to discern from the CISG general principles such as estoppel (or in civilian language non venire contra factum proprium) and the avoidance of economic waste, and possibly even the principle of good faith and fair dealing. ${ }^{74}$ Although there is a case for having a general convention on substantive contract law that sits comfortably with the CISG ${ }^{75}$ the patient, deliberate and time-consuming process of interpreting the CISG and filling its gaps can be taken so far that there is either no or very little utility in bringing in the PICC to supplement the

72 In the drafting process, an attempt was made in Article 3(2) but later abandoned to render certain instruments that were not state-based law eligible for treatment as the applicable law ("the principles and rules of the substantive law of contract recognized internationally or in the Community"). The existence of a role for non-state law is permitted by the Inter-American Convention on the Law Applicable to International Contracts 1994, Articles 9 (duty of court to "take into account the general principles of international commercial law recognized by international organizations") and 10 ("The guidelines, customs, and principles of international commercial law as well as commercial usage and practices generally accepted shall apply in order to discharge the requirements of justice and equity in the particular case").

73 See, for example, Article 28(1) of the UNCITRAL Model Law on Arbitration ("such rules of law as are chosen by the parties as applicable to the substance of the dispute").

74 The difficulty in this instance lies in determining the meaning of the rejection on an express duty of good faith binding on the contracting parties.

75 A Swiss proposal in 2012 ((A/CN.9/758)) for a complementary commercial contract instrument to the CISG was not accepted by UNCITRAL. 
CISG ${ }^{76}$ Apart from validity and property, the CISG governs the rights and obligations of seller and buyer without any further exclusion. ${ }^{77}$

Assuming however some utility in the process (methods of payment being a good example), a question that must be answered concerns the legitimacy of invoking the PICC. There is the obvious difficulty of invoking a later instrument, the PICC, as a foundation for the earlier CISG. How can it be said that the PICC were the basis upon which the CISG was concluded? Apart from Article 7(2) CISG, however, there is Article 9 CISG which deals with the role accorded to usage. Usage is formed by established practices between parties, whether it is the parties to the existing contract or parties in the trade in general. The whole of the PICC, which amount to something in the nature of a contract code far transcending trade practices, cannot be taken to be usage. An area omitted from the CISG is vitiating factors such as duress and fraud. These are dealt with amply by the PICC but how can it be said that these rules are a matter of usage? Moreover, the Preface to the PICC makes it clear that rules were selected because of their intrinsic merits and not because of their widespread recognition. Particular rules, however, might pass the usage test but this can only be settled on a rule by rule basis. The rules on payment and related matters in the $\mathrm{PICC}^{78}$ might just pass the usage test, but the result of this investigation overall is that the PICC adds little to the CISG. This is in part due to the scale of the CISG itself which contains numerous rules, express and implied, that could sit well in a general contract law.

Turning our attention now to the PICC as a global expression of contract law, a perceptive survey of them has been made appraising the extent of their usefulness and success. ${ }^{79}$ It points out how little use is made of the PICC in the selection of an applicable law but that arbitrators do make use of them, though as individual rules rather than an overall system, even in the absence of choice by the parties. This latter finding is not surprising. The PICC represent an attractive alternative to invoking a complex choice of law process to reach the relevant rule in a national set of rules that might be difficult to discern and understand. The selection and application of the law applicable to a contract by arbitrators is often an

76 Michael Bridge, "The CISG and the UNIDROIT Principles of International Commercial Contracts”, Uniform Law Review, Vol. 19, 2014, 623.

77 Article 4 CISG.

78 Articles 6.1.7 et seq PICC.

79 Ralf Michaels, “The UNIDROIT Principles as Global Background Law", Uniform Law Review, Vol. 19, 2014, 643. 
occult affair. Their awards are not open to external scrutiny except in extreme ca$\operatorname{ses}^{80}$ and the presence of a body of decisions amplifying and clarifying the meaning of the PICC is not to be found. This may explain the reluctance of parties and their legal advisers when it comes to selecting the PICC, which represent the equivalent of a Potemkin village (or something in a Hollywood backlot), all facade and nothing behind them. The above survey, ${ }^{81}$ however, sees no small measure of success in the PICC as "global background law", operating "more as objective law than as an object of choice". They operate not so much as a global legal instrument but rather as a touchstone against which legislators and courts measure national legislation and decisions. This is an intriguing idea but this overall finding, that the PICC are not unimportant, amounts to significantly less than their success as an expression of global contract law.

\section{CONCLUSION}

We remain a long way from achieving a global contract law. The CISG has been remarkably successful in the particular case of sale, but a count of the number of Contracting States gives less than an account of how often the CISG applies to contracts of sale. In fact, it is positively misleading to count the number of Contracting States and then to recite the percentage of world trade for which these States are responsible. The CISG is very commonly excluded in international contracts and, in my experience, is almost always excluded in the sale of commodities. This is largely because its commitment to keeping the contract alive does not sit well with the harsh economics of dynamic and shifting markets. For many traders participating in international commodity sales, they may as well be dealing with an abstract entity such as a swap or an option. They will never see the physical goods and may not even see the shipping documents if provision is made for a truncated collection at the end of a sales string. It is also because market participants, believing they already have a measure of legal certainty, are resistant to legal change. There is no real prospect of UNCITRAL or UNIDROIT devoting extensive resources to the creation of a global contract law given the pressing nature of the need to deal with vital developments, such as dealings in dematerialised securities and international security interests. It is likely to be the case for

80 New York Convention on the Recognition and Enforcement of Foreign Arbitral Awards 1958, Article V.

81 R. Michaels, op. cit., 643. 
some considerable time to come that cross-border contracts remain subject to national rules, with the choice of law process continuing to play a prominent role. René David once remarked that choice of law should not impede the expansion of uniform law by according to national law too great a role, even when visited through uniform rules of private international law. ${ }^{82}$ That said, evolution in biological terms is a slow process and, even in those cases where it picks up speed, its progress is measured in generations. This summary so far pays scant regard to the globalised use of standard form contracts. It is hard to overestimate the importance of these forms in promoting the process of globalisation in contractual matters, but in furthering the use of a particular national law they do not create a globalised contract law. The same might be said for the banks of precedents compiled by multinational law firms.

\author{
MICHAEL G. BRIDGE QC (Hon), FBA \\ Profesor na Geoffrey Bartholomew, \\ National University of Singapore \\ Profesor Emeritus na London School of Economics
}

\title{
MEĐUNARODNA TRGOVINA I TRANSNACIONALNO PRAVO
}

\section{Rezime}

Predmet ovog rada odnosi se na globalizaciju ugovornog prava. U radu je najpre data istorijska analiza ovog pitanja, a zatim je učinjen pogled na različite vrste uniformnih pravila. Neka od njih predstavljaju "tvrdo" pravo, kao što su multilateralne konvencije, dok druga ulaze u kategoriju pravila "mekog" prava, koja uključuju neobavezujuće pravne instrumente koje ugovorne strane i suverene države mogu primenjivati. U tu kategoriju ulaze ugovorni opšti uslovi (npr. Incoterms 2020) i model ugovori (npr. ISDA ugovori), kao i model zakoni UNCITRAL-a. U radu je učinjen osvrt na ulogu nacionalnog prava u procesu globalizacije, putem uticaja na zakone drugih država ali i kroz doprinos u stvaranju uniformnog zakona. U radu su analizirana pravila Konvencije UN o međunarodnoj prodaji robe (CISG), razmotren je uticaj kontinentalnog i anglosaksonskog prava na njena rešenja i podvučen je značaj uniformnog karaktera Konvencije. Na kraju rada, pažnja je posvećena ulozi i značaju UNIDROIT Načela međunarodnih trgovinskih ugovora (PICC) u oblasti uniformnog ugovornog prava.

Ključne reči: lex mercatoria, tvrdi zakon, meki zakon, uniformno pravo, nachfrist, otklanjanje neispunjenja, ublažavanje

82 International Encyclopaedia of Comparative Law, Vol II: The Legal Systems of the World/ Their Comparison and Unification, Ch 5 “The International Unification of Private Law", Brill, 1981, para 62 . 
Bibliography

Bridge M., "The CISG and the Unidroit Principles of International Commercial Contracts", Uniform Law Review, Vol. 19, 2014.

Coggan Ph., More: The 10,000 Year Rise of the World Economy, The Economist Books, London, 2020.

Hobhouse S.J., "International Conventions and Commercial Law: the Pursuit of Uniformity", The Law Quarterly Review, Vol. 106, 1990.

Huet J., Traité de droit civil. Les principaux contrats spéciaux, LGDJ, Paris, 2001.

Kötz H., European Contract Law, Oxford, 2nd edn, 2017.

Michaels R., “The UNIDROIT Principles as Global Background Law”, Uniform Law Review, Vol. 19, 2014.

Mybergh P., "A Successful Substantivist Carve-Out?: The Athens Convention as Uniform International Law", Journal of Business Law, 2020.

Pollock S.F., Maitland F.W., The History of English Law, SFC Milson, Cambridge, 2nd edn, Vol. 1, 1968.

Postand C., Miller E., The Cambridge Economic History of Europe, Cambridge, 2nd edn, Vol II, 1987.

Van Caenegem R., An Historical Introduction to Private Law, Cambridge, 1992.

Wang Ch. H., The German Civil Code: Translated and Annotated, Stevens, 2007.

Will M., "Article 48", Commentary on the International Sales Law, Michael Joachim Bonell, C. Massimo Bianca (eds.), Milan, 1987.

Windeyer W. J. V., Lectures on Legal History, Law Book Co of Australasia, Sydney, 1949.

Zimmermann R., The New German Law of Obligations, Oxford, 2005.

Article history

Received: 07.09.2020.

Accepted: 25.09.2020.

ORIGINAL SCIENTIFIC PAPER 